\title{
Middle school teacher pedagogic competency map for private vocational school in Wanareja Cilacap
}

\author{
Rahmat Basuki*, Edhy Susatya, Bambang Noor Achsan Kristiyanto \\ Universitas Ahmad Dahlan, Jl. Pramuka, Yogyakarta, Indonesia \\ *E-mail: mang.rahmat@gmail.com
}

\begin{abstract}
This study aims to map the acquisition of teachers' pedagogical competence at private vocational high schools Wanareja, Cilacap, Central Java. This research used quantitative method. We involved 60 teachers from four private vocational schools as the research subject. We delivered a Likert-scale questionnaire to assess the pedagogical competence. Then, we analyzed the data using non-parametric inferential statistics. The results showed that the pedagogical competence of private vocational school teachers in Wanareja on ten aspects of pedagogical competence had different categories in each aspect. The aspect of mastering the students' characteristics was very sufficient $(55 \%)$. The aspect of mastering the learning theory was good $(44 \%)$ and very sufficient $(40 \%)$. The aspect of developing a curriculum was good (48\%). The aspect of organizing learning was good (63\%). The aspect of using ICT in learning was very sufficient $(51 \%)$. The aspect of developing the students' potential was good (44\%). The aspect of effective communication and politeness was good (63\%). The aspect of conducting an assessment was sufficient (53\%). The aspect of utilizing the results of the assessment for the benefit of learning was very sufficient (53\%). And finally, the aspect of doing reflective action was sufficient $(68 \%)$. The implementation of the pedagogical competence of private vocational school teachers in Wanareja has not been evenly distributed in all aspects of competencies and efforts to improve teacher pedagogical competence has not been maximized.
\end{abstract}

Keywords: competency map, pedagogy, vocational teachers

How to cite: Basuki, R., Susatya, E., \& Kristiyanto, B. N. A. (2021). Middle school teacher pedagogic competency map for private vocational school in Wanareja Cilacap. International Journal on Education Insight, 2(1), 37-44. DOI: 10.12928/ijei.v2i1.4009

\section{INTRODUCTION}

Improving the quality of human resources and improving the quality of education must begin with improving the quality of teachers towards professional teachers. Currently, there are still many obstacles and challenges faced, especially in the implementation of learning (Musfah, 2015). Teacher professionalism increases, if the teacher can implement all competencies in learning activities so that quality learning will be realized, namely learning that can increase motivation, develop potential, and produce learning achievement of students.

Saggaf et al. (2017) stated that there are four competencies that teachers must have to achieve their professional duties, namely pedagogical ability, personality competence, social competence, and professional competence. Teachers have a strategic role in improving the quality of learning. The development of pedagogic competencies is an important factor for the continuity of the learning process of students so that it can produce achievements for students.

Saggaf et al. (2017) stated that one of the main factors that determine the quality of education is the teacher. A teacher is someone who is at the forefront 
of improving the quality of human resources. It can be said that without a teacher, the world will end. The teacher will produce quality students, both in terms of cognitive, affective, and psychomotor. Therefore, qualified teachers are needed so that future generations can face all challenges in the future. Teachers are expected to have qualifications and competencies in carrying out their duties).

According to Megawati (2013), a professional teacher must have at least four basic abilities (competencies) and an attitude as a teacher who gets the trust to prepare for the nation's future. The four abilities are: (1) mastering the curriculum, (2) mastering subject matter, (3) mastering methods and evaluation and implementation, and (4) having high commitment and discipline in carrying out tasks. Teachers must have complete competence, both pedagogical, professional, personal, and social competencies. so that the learning process is more efficient and effective.

De facto, the work of teachers has not all shown a professional job, because in practice there are still many violations of the code of ethics of their specialty, both in planning, implementing and monitoring and evaluating teacher work. There are also teacher jobs that are carried out by people who have backgrounds that do not match their education so that the quality of education is low both in the process and in the results of the examinations (Mulyasa, 2017).

For teachers who take the Teacher Competency Test, only a small proportion get 5.0 and above, most only get a score of 3.0. The UKG results show that only $43 \%$ of Indonesian teachers are declared professional, while the other $57 \%$ are still not professional (Mulyasa, 2017).

The pedagogical competence of private vocational school teachers in Wanareja District, Cilacap Regency, based on the results of monitoring and assistance for the implementation of the 2013 curriculum, have not shown mastery of ideal pedagogical competences, but the authors do not know for sure which core competencies private SMK teachers in Wanareja District, Cilacap Regency have not mastered, have not been implemented, and how our efforts to improve pedagogical competencies that are not maximized. Activities that lead to systematic, planned, and a massive improvement in teacher quality in private SMK in Wanareja District, Cilacap Regency are also still minimal, so any mastery of pedagogical competencies needs to be considered and studied in depth.

Danim (2002) states that professional people have different attitudes from unprofessional people even though they are in the same job or say in one workspace. Therefore, professional teachers always have their characteristics in their daily lives to always show their proficiency as a teacher. To professionalize a job, including the profession as a teacher, Wilensky formulates five steps, namely: (1) creating a full-time or full-time job, not a part-time job, (2) determine the school as a place to undergo the education or training process, (3) establish a professional association, (4) agitating politically to fight for the existence of legal protection for the association or association, (5) formally adopt the established code of ethics (Suhandani \& Julia, 2014).

Umami (2014) stated that teacher pedagogical competence has a very central role in the learning process in the classroom. Therefore, this competency is one of the important competencies that must be mastered by teachers. This pedagogic competence is the teacher's ability to carry out the learning process in the classroom which includes the ability to understand students, the ability to carry out learning design, the ability to evaluate learning, and the ability to develop student potential.

IJEI, Vol. 2, No. 1, April 2021, 37-44 
According to Iswantoro and Suryana (2016), pedagogical competence is the ability of teachers to mastery of theory and application in the learning, teaching, and education process, which are essential and fundamental, so it is very important to know teacher pedagogical competence, implementation, and efforts to improve these competencies so that teachers are realized. professional one

Kusnandar (2007) describes pedagogical competence as the ability to: (1) understand students in-depth, (2) design learning including understanding the educational foundation for learning purposes, (3) implementing learning by arranging learning backgrounds or settings, and implementing conducive learning, (4) designing and implementing continuous evaluation of learning with various methods, analyzing the results of process evaluation and learning outcomes, and (5) developing the academic and non-academic potential of students. Pedagogic competence is defined as the teacher's ability about theoretical mastery and the application process in learning both in managing learning by designing and implementing the learning process following the applicable educational foundation, as well as the ability to develop the potential of students.

Mulyasa (2011) states that teacher competency tests should be carried out continuously, to determine the development of teacher professionalism. Thus the results of the teacher competency test can be used at any time, both for promotion, placement, and giving awards to teachers.

Vocational High School (SMK) is one of the levels of secondary education with the specialty of preparing graduates to be ready for work. Education vocational has various meanings but a common thread can be seen. Djojonegoro (1998) defines that vocational education is part of the education system that prepares a person to be better able to work in a group of jobs or one occupation than in other fields of work. With the understanding that each field of study in vocational education as long as the field of study is studied more deeply and this depth is intended as a provision to enter the world of work.

According to Peters' opinion, there are three teacher duties and responsibilities, namely the teacher as a teacher, the teacher as a guide, and the teacher as a class administrator. Teachers are required to have the ability to have a set of teaching knowledge and technical skills as well as to master the knowledge or material to be taught. The teacher as a guide emphasizes the task of providing assistance and solutions to problems faced by students. Meanwhile, the teacher as a class administrator is essentially a link between the management of the subject area.

\section{RESEARCH METHOD}

This research is quantitative. According to Sugiyono (2019), the quantitative method is a method used to generalize an observation of a reality that occurs. The purpose of the study was to map the mastery of teacher pedagogical competence, analyze the implementation of teacher pedagogic competence in the learning process, and analyze efforts to improve the pedagogic competence of private vocational school teachers in Wanareja District, Cilacap Regency.

The research was conducted on private vocational teachers in Wanareja sub-district as research subjects. Teachers of four schools in Wanareja District were used as data sources which were revealed through a structured questionnaire/questionnaire instrument. While the object of the research is the core competence of teachers from pedagogical competence.

The data source comes from primary data which is data obtained directly from respondents as many as 60 teachers through a questionnaire. Primary 
data of the study were obtained from private vocational school teachers in Wanareja sub-district, Cilacap Regency, while secondary data were data taken from documents related to research, such as; syllabus documents, RPP, and list of values.

\section{RESULTS AND DISCUSSION}

The research data related to the pedagogic competency map of private vocational school teachers in Wanareja District, Cilacap Regency were processed by identifying in the average form, the score for each aspect of pedagogic competence, the percentage, and predicate of each item in one aspect of pedagogic competence, then described in the form of a teacher pedagogic competency mapping. Private vocational high schools in Wanareja District, Cilacap Regency which cover:

\section{Aspects of understanding the characteristics of students}

The data was taken using an instrument using a Likert scale by calculating the average answer based on the score of each respondent's answer. The competence of private Vocational High School teachers in Wanareja District for the aspect of understanding the characteristics of the students being taught, of the respondents 60 teachers were categorized as very sufficient, 33 teachers $55 \%), 24$ teachers (40\%) were an insufficient category, and 3 teachers $(5 \%)$ were categorized as lacking in understanding the characteristics of students.

\section{Aspects of theory of learning}

The results data from 60 respondents from 4 private vocational schools in Wanareja District regarding pedagogical competence in the theoretical aspects of learning and educational learning show that teachers who understand the theory of learning and teaching-learning in the learning process are categorized as very good as 5 teachers $(8.33 \%) 26$ teachers $(43.33 \%)$ in the good category, 24 teachers $(40 \%)$ in very sufficient category, and 5 teachers $(8.33 \%)$ inadequate category.

\section{Aspects of developing a curriculum}

Obtaining data from respondents about the pedagogical competence of curriculum development aspects shows the competence of private vocational school teachers in Wanareja District in the aspect of developing curriculum from 60 teachers, there are 15 teachers (25\%) categorized as close to very good, 22 teachers $(48.33 \%)$ good category, 16 teachers $(26.67 \%)$ very sufficient category. In this case, the majority of the teachers in the category approach very well and are good at developing the curriculum.

\section{Aspects of organizing educational learning}

Obtaining data on the pedagogical competence of the aspect of conducting learning, shows that the competence of private vocational school teachers in Wanareja District in the aspect of organizing educational learning from 60 teachers, 13 teachers $(21.67 \%)$ are categorized as close to very good, 38 teachers $(63.33 \%)$ are in a good category, 8 teachers $(13.33 \%)$ in the very sufficient category and 1 teacher $(1.67 \%)$ in the sufficient category. In this case, the majority of teachers in the category approach very well and good. 


\section{Aspects of using ICT in learning}

The pedagogic competence aspects of utilizing ICT in learning show that the competence of private vocational school teachers in Wanareja District, from 60 teachers, there are 2 teachers $(3.33 \%)$ categorized as close to very good, 27 teachers $(45 \%)$ in the good category, 31 teachers $(51.67 \%)$ very pretty category. The diagram illustrates the aspects of utilizing ICT in learning, there are categories of teachers who are close to being very good and good, but the majority of teachers, namely $51.67 \%$, are categorized as sufficient.

\section{Aspects of developing the potential of students}

Pedagogic competence in the aspect of developing the potential of students shows the competence of private vocational school teachers in Wanareja District, there are 19 teachers $(31.67 \%)$ categorized as close to very good, 28 teachers (46.67\%) good category, 13 teachers $(21.66 \%)$ very sufficient category. In the pedagogic competency aspect of developing the potential of students, the majority of teachers are in the very good and good category, but there are still some teachers, namely $46.67 \%$, the category is sufficient, even though developing the potential of students is very important in achieving the competencies to be achieved.

\section{Aspects of communicating effectively, empathically, and courteously}

Pedagogic competence in communicating effectively, emphatically, and politely shows the competence of private vocational school teachers in Wanareja District, 12 teachers (20\%) are categorized as close to very good, 38 teachers $(63.33 \%)$ are good, 10 teachers $(16.67 \%)$ sufficient. Overall, the majority of teachers in the category approached very well and good, but there were still some teachers, reaching $16.67 \%$ of the category around sufficient.

\section{Aspects of conducting assessment and learning outcomes}

Pedagogic competence in the aspect of conducting assessments and learning outcomes, from the correspondence of 60 teachers there is 1 teacher $(1.67 \%)$ in the very good category, 32 teachers $(23.33 \%)$ are good, 32 teachers $(53.33 \%)$ are very sufficient, 13 teachers $(21.67 \%)$ was sufficient, but the majority were still in the adequate category reaching $53.33 \%$.

\section{Aspects of using assessment results for learning}

There are 7 teachers $(11.67 \%)$ in good category pedagogical competence, 36 teachers $(60 \%)$ very sufficient, 17 teachers $(28.33 \%)$ sufficient, but the majority of teachers have sufficient competence which is more than $80 \%$.

\section{Aspects of reflective action for quality of learning}

Pedagogic competence in the aspect of reflective action to improve the quality of learning from 60 respondents, there were 6 teachers $(10 \%)$ in the very sufficient category, 41 teachers $(68.33 \%)$ sufficient, 13 teachers $(21.67 \%)$ in the poor category, but the majority of teachers had competence enough for $78 \%$ and $21.67 \%$ for the poor category.

Implementation of pedagogic competence of private vocational school teachers in Wanareja District, Cilacap Regency, there are 50\% of teachers in good category, $45 \%$ in very sufficient category, and $5 \%$ in enough category.

Efforts to increase the pedagogic competence of private vocational school teachers in Wanareja District, Cilacap Regency, there are $75 \%$ in the sufficient 
category, $8.3 \%$ in the very sufficient category and 16.7 in the poor category. The details can be seen in Table 1.

Table 1. Results for each aspect

\begin{tabular}{|c|c|c|c|}
\hline No & $\begin{array}{c}\text { Aspects of Pedagogic } \\
\text { Competence }\end{array}$ & Percentage & Category \\
\hline 1 & $\begin{array}{l}\text { Mastering the } \\
\text { characteristics of students } \\
\text { from physical, moral, } \\
\text { spiritual, social, cultural, } \\
\text { emotional, and intellectual } \\
\text { aspects }\end{array}$ & $\begin{array}{c}55 \% \\
40 \% \\
5 \%\end{array}$ & $\begin{array}{l}\text { Very Enough } \\
\text { Enough } \\
\text { Less }\end{array}$ \\
\hline 2 & $\begin{array}{l}\text { Mastering learning theory } \\
\text { and learning principles }\end{array}$ & $\begin{array}{l}44 \% \\
40 \% \\
8 \% \\
8 \%\end{array}$ & $\begin{array}{l}\text { Good } \\
\text { Very Enough } \\
\text { Enough } \\
\text { Very Good Approaching }\end{array}$ \\
\hline 3 & $\begin{array}{l}\text { Developing a curriculum } \\
\text { related to the subjects } \\
\text { being taught. }\end{array}$ & $\begin{array}{l}48 \% \\
27 \% \\
25 \%\end{array}$ & $\begin{array}{l}\text { Good } \\
\text { Very Enough } \\
\text { Very Good Approaching }\end{array}$ \\
\hline 4 & $\begin{array}{l}\text { Organizing educational } \\
\text { learning }\end{array}$ & $\begin{array}{c}63,33 \% \\
21 \% \\
13,33 \%\end{array}$ & $\begin{array}{l}\text { Good } \\
\text { Very Good Approaching } \\
\text { Very Enough }\end{array}$ \\
\hline 5 & $\begin{array}{l}\text { Utilizing ICT for the benefit } \\
\text { of learning }\end{array}$ & $\begin{array}{l}51,67 \% \\
45 \% \\
3,33 \%\end{array}$ & $\begin{array}{l}\text { Very Enough } \\
\text { Good } \\
\text { Very Good Approaching }\end{array}$ \\
\hline 6 & $\begin{array}{l}\text { Development of the potential } \\
\text { of students }\end{array}$ & $\begin{array}{l}46,67 \% \\
31,67 \% \\
21,66 \%\end{array}$ & $\begin{array}{l}\text { Good } \\
\text { Very Good Approaching } \\
\text { Very Enough }\end{array}$ \\
\hline 7 & $\begin{array}{l}\text { Communicate effectively, } \\
\text { empathically, and politely } \\
\text { with students }\end{array}$ & $\begin{array}{l}63,33 \% \\
16,67 \%\end{array}$ & $\begin{array}{l}\text { Good } \\
\text { Very Enough }\end{array}$ \\
\hline 8 & $\begin{array}{l}\text { Carry out an assessment } \\
\text { and evaluation of the } \\
\text { learning outcome process }\end{array}$ & $\begin{array}{c}53,33 \% \\
23,33 \% \\
1,67 \%\end{array}$ & $\begin{array}{l}\text { Enough } \\
\text { Good } \\
\text { Very Good Approaching }\end{array}$ \\
\hline 10 & $\begin{array}{l}\text { Make use of the results of } \\
\text { the assessment and } \\
\text { evaluation for the benefit of } \\
\text { learning } \\
\text { Reflective take action to } \\
\text { improve the quality of } \\
\text { learning }\end{array}$ & $\begin{array}{c}53,33 \% \\
23,33 \% \\
21,67 \% \\
1,67 \% \\
68,33 \% \\
21,67 \% \\
10 \% \\
\end{array}$ & $\begin{array}{l}\text { Very Enough } \\
\text { Good } \\
\text { Enough } \\
\text { Very Good Approaching } \\
\text { Enough } \\
\text { Less } \\
\text { Very Enough }\end{array}$ \\
\hline
\end{tabular}

Based on Table 1, it can be seen that the highest percentage in each aspect of the pedagogical competence of private vocational school teachers in Wanareja District is as follows. The first competency, the aspect of mastery of the characteristics of students, was that $55 \%$ of the teachers were in the very sufficient category, $40 \%$ of the teachers were in the sufficient category, and $5 \%$ were in the poor category.

The second competency that stands out, in the competence of mastery of learning theory and learning principles, there are $44 \%$ good, $40 \%$ very sufficient, 
and $8 \%$ sufficient, and $8 \%$ close to very good. In the third competency aspect, there are $48 \%$ good category curriculum development, $27 \%$ very sufficient, and $25 \%$ close to very good. The competence of the fourth aspect of the implementation of educational learning is $63.33 \%$ in the good category, $21 \%$ close to very good, and $13.33 \%$ very sufficient. The fifth aspect of the benefits of ICT in learning is that $45 \%$ of teachers are categorized as good, and $51.67 \%$ are very sufficient, and $3.33 \%$ are close to good categories.

The aspect of developing the potential of students as the sixth aspect, there are $46.67 \%$ good categories, $31.67 \%$ close to very good categories, and $21.66 \%$ very sufficient categories. In the seventh aspect, which is communicating effectively and politely with students, there are $63.33 \%$ good category competency teachers and $16.67 \%$ very sufficient category. The eighth aspect is the implementation of assessment and learning outcomes, there is $53.33 \%$ in the sufficient category, $23.33 \%$ in the good category, and $1.67 \%$ for the teachers in the very good category.

In the ninth aspect, namely the use of assessment, there were $53.33 \%$ of teachers in the very sufficient category, $23.33 \%$ in the good category, $21.67 \%$ in enough category, and $1.67 \%$ in the very good category. The tenth aspect, namely reflective action for the quality of learning, contained $68.33 \%$ of teachers insufficient category, $21.67 \%$ in the poor category, and $10 \%$ in the very sufficient category.

Based on the research results, of the ten aspects of pedagogical competence, several aspects must receive special attention for private vocational school teachers in Wanareja District to be improved, namely the first aspect, mastery of student characteristics, aspect eight, organizing assessment and learning outcomes, aspect nine, the use of assessment for learning; and ten aspects, reflective action for the quality of learning. The four aspects of pedagogic competence are categorized as sufficient, so it is necessary to increase the competence of private vocational school teachers in Wanareja District, Cilacap Regency to become professional teachers.

Implementation of pedagogic competence in the learning process, private vocational school teachers in Wanareja District, Cilacap Regency, have various categories of pedagogical competence concepts. The percentage of implementation of teacher pedagogic competence was $50 \%$ in the good category, $45 \%$ of teachers in the very sufficient category, and 5\% insufficient category. This illustrates that the implementation of pedagogical competencies is still not optimal, as evidenced by the aspects of the existing core competencies, not all have been implemented in the learning process.

Based on the results of the above research, if it is related to the theory presented by Iswantoro and Suryana (2016), regarding the importance of pedagogic competence, that pedagogic competence is the teacher's ability to mastery of theory and application in the learning, teaching, and educating process, which is essential and fundamental, it is very important. It is important to know teacher pedagogical competence, implementation, and efforts to improve these competencies to create professional teachers.

The teacher's efforts to overcome these problems, among others, have reactivated MGMP activities and motivated them to take part in scientific activities, such as; training, seminars, workshops related to improving teacher quality. Teacher competency quality improvement and assessment programs can also be carried out by participating in various pieces of training/training, courses, and MGMP activities. 
The results of the above research show the importance of teacher professional development training, curriculum workshops, MGMP, as an activity to improve teacher competence, but participating in these activities must be tailored to the needs so that it will be more beneficial for both teachers and students.

\section{CONCLUSION}

The pedagogical competence of private vocational school teachers in Wanareja District, Cilacap Regency has different categories. In certain aspects, it is categorized as good, in other aspects it is categorized as sufficient and less. In the implementation of the pedagogical competence of private vocational school teachers in Wanareja District, Cilacap Regency, it has not been evenly distributed in all competency aspects. In certain aspects it is good, in other aspects it is in enough and inadequate categories.

Efforts to improve the pedagogical competence of private vocational school teachers in Wanareja District, Cilacap Regency have been carried out through several activities, including involving teachers in various competency enhancement pieces of training, but the follow-up of these activities has not been carried out optimally, and teacher performance appraisal (PKG) activities have not been carried out.

\section{REFERENCES}

Danim, S. (2002). Inovasi Pendidikan dalam Upaya Peningkatan Profesionalisme Tenaga Kependidikan. Bandung: Pustaka Setia.

Iswantoro, N., \& Suryana. Y. (2016). Kompetensi Pedagogik Guru. Surabaya: Genta Group Production.

Kusnandar. (2007). Guru Profesional, Implementasi Kurikulum Tingkat Satuan Pendidikan. Jakarta: Rajawali Press.

Megawati, S. (2013). Meningkatkan hasil belajar siswa kelas XI SMK Negeri 1 Parigi pada mata pelajaran IPA Biologi melalui pembelajaran kooperatif model Think-Pair-Share. Jurnal Kreatif Online, 2(4), 331-342.

Mulyasa, E. (2011). Menjadi Guru Profesional. Bandung: Remaja Rosdakarya.

Mulyasa, H. E. ( 2017). Uji Kompetensi dan Penilaian Kinerja Guru. Bandung: Remaja Rosdakarya.

Musfah, J. (2015). Peningkatan Kompetensi Guru melalui Pelatihan dan Sumber Belajar, Teori dan Praktik. Jakarta: Kencana.

Umami, D. R. (2014). Pengaruh kompetensi pedagogik dan motivasi kerja guru terhadap prestasi belajar siswa dalam ujian nasional (UN) di SMA Negeri se-Kota Mojokerto. Inspirasi Manajemen Pendidikan, 3(3).

Saggaf, M. S., Salam, R., \& Wirawan, H. (2017). The influence of teacher's pedagogic competence on learning motivation of student of office administration expertise package. In 8th International Conference of Asian Association of Indigenous and Cultural Psychology (ICAAIP 2017). Atlantis Press.

Sugiyono. (2019). Metode Penelitian Pendidikan. Bandung: Alfabeta.

Suhandani, D., \& Julia, J. (2014). Identifikasi kompetensi guru sebagai cerminan profesionalisme tenaga pendidik di Kabupaten Sumedang (Kajian pada kompetensi pedagogik). Mimbar Sekolah Dasar, 1(2), 128141.

IJEI, Vol. 2, No. 1, April 2021, 37-44 